\title{
Recent Articles in Ageing Research
}

List No. 15, collected February-April, 1975

As a regular feature of Gerontologia, the Editors publish in each issue a selection of recent articles in all fields of ageing research covered by this journal, appearing in other journals in this field and in some multi-disciplinary journals generally accessible to most readers. The selection does not intend to be complete, but to present articles which, in the opinion of the Editors, will be of interest to our readers. The Editors are responsible for the selection, but invite readers to bring to their attention articles which they think should be included in the next list.

The articles are ordered alphabetically under the following subject headings: (1) General, (2) Biochemistry, (3) Metabolism, (4) Cell Culture, (5) Physiology and Cell Biology, (6) Immunology, (7) Histology, Cytology and Comparative Anatomy, (8) Pharmacology, (9) Longevity, Populations and Genetics, (10) Plants, and (11) Psychology and Behaviour. Biochemistry Baird, M. B.; Nicolosi, R. J.; Massie, H. R., and Samis, H. V.: Microsomal mixedfunction oxidase activity and senescence. I. Hexobarbital sleep time and induction of components of the hepatic microsomal enzyme system in rats of different ages. Expl Gerontol. 10: 89-100 (1975). Britton, G. W. and Sherman, F. G.: Altered regulation of protein synthesis during aging as determined by in vitro ribosomal assays. Expl Gerontol. 10: 67-78 (1975). Carter, D. B. and Chae, C.-B.: Composition of liver histones in aging rat and mouse.

J. Geront. 30: 28-32 (1975). Chetsanga, C. J.; Boyd, V.; Peterson, L, and Rushlow, K.:

Singlestranded regions in

DNA of old mice. Nature, Lond. 253: 130 (1975). Comolli, R.: Deficiency in accessory protein of native $40 \mathrm{~S}$ ribosomal subunits in the liver

of aging rats. Expl Gerontol. 10: 31-36 (1975). Cutler, R. G.: Transcription of unique and reiterated DNA sequences in mouse liver

and brain tissues as a function of age. Expl Gerontol. 10: 37-60 (1975). Ferioli, M. E. and Comolli, R.: Changes of liver and kidney polyamine levels during

aging. Expl Gerontol. 10: 13-16 (1975). Goldberg, P. B.; Baskin, S. I., and Roberts, J.: Effects of aging on ionic movements of

atrial muscle. Fed. Proc. 34: 188-191 (1975). Gusseck, D. J.: Anomalies in the tRNAaminoacylation reaction which could lead to

misinterpretation of evidence for tRNA changes during development and aging.

Mech. Age Dev. 3: 301-310 (1975). Kaldor, G. and Min, B. K.: Enzymatic studies on the skeletal myosin A and actomyosin

of aging rats. Fed. Proc. 34: 191-194 (1975). Kanungo, M. S.; Patnaik, S. K., and Koul, O.:

Decrease in $17 ß$-oestradiol receptor in

brain of ageing rats. Nature, Lond. 253: 366 (1975). Liew, C. C. and Gornall, A. G.: Covalent modification of nuclear proteins during aging.

Fed. Proc. 34: 186-187 (1975). Lundholm, K. and Scherstén, T.: Leucine incorporation into proteins and cathepsin-D 
activity in human skeletal muscles. The influence of the age of the subject. Expl Gerontol. 10: $155-159$ (1975).

246

Recent Articles in Ageing Research

Ogrodnik, J. P.; Wulf, J. H., and Cutler, R. G.: Altered protein hypothesis of mammalian ageing processes. II. Discrimination ratio of methionine vs. ethionine in the synthesis of ribosomal protein and RNA of C57BL/6J mouse liver. Expl Gerontol. 10: 119-136 (1975).

Padhi, S. C. and Patnaik, B. K.: Ageing changes in the brain of the garden lizard, Calotes versicolor. III. Free amino acid and ascorbic acid contents in whole brain and brain parts. Expl Gerontol. 10: 61-66 (1975).

Padhi, S. C. and Patnaik, B. K.: Age-changes in basic proteins of the brain and brain parts in the male garden lizard. Expl Gerontol. 10: 137-140 (1975).

Panigraphy, G. K. and Patnaik, B. K.: Effect of somatotropin on the collagen contents of bone, cartilage and tendon in young male garden lizards. Expl Gerontol. 10: 85-87 (1975).

Platt, D. and Schoch, P.: Effect of age and cardiac glycosides on the activity of adenosine triphosphatase (ATPase) (E.C. 3.6.1.3) of red cell ghost membranes. Mech. Age Dev. 3: 245-252 (1975).

Roth, G. S. and Adelman, R. C.: Age-related changes in hormone binding by target cells and tissues; possible role in altered adaptive responsiveness. Expl Gerontol. 10: 1-12 (1975).

Wulf, J. H. and Cutler, R. G.: Altered protein hypothesis of mammalian ageing processes. I. Thermal stability of glucose-6-phosphate dehydrogenase in C57BL/6J mouse tissue. Expl Gerontol. 10: 101-118 (1975).

Metabolism Adelman, R. C.: Impaired hormonal regulation of enzyme activity during aging. Fed.

Proc. 34: 179-182 (1975). Bulos, B. A.; Shukla, S. P., and Sacktor, B.: Bioenergetics of mitochondria from flight

muscle of aging blow-flies: partial reactions of oxidation and phosphorylation. Archs

Biochem. Biophys. 166: 639 (1975). Finch, C. E.; Jonec, V.; Hody, G.; Walker, J. P.; Morton-

Smith, W.; Alper, A., and

Dougher, G. J.: Aging and the passage of L-tyrosine L-dopa, and inulin into mouse

brain slices in vitro. J. Geront. 30: 33-40 (1975). Gillette, J. R. and Stripp, B.: Pre- and postnatal enzyme capacity for drug metabolite

production. Fed. Proc. 34: 172-178 (1975). Hanson, R. W.; Reshef, L., and Ballard, J.: Hormonal regulation of hepatic P-enol-

pyruvate carboxykinase (GTP) during development. Fed. Proc. 34: 166-171 (1975). Roth, G. S.:

Age-related changes in glucocorticoid binding by rat splenic leukocytes:

possible cause of altered adaptive responsiveness. Fed. Proc. 34: 183-185 (1975).

Cell Culture Goldstein, S. and Trieman, G.: Glucose consumption by early and late-passage

diploid

human fibroblasts during growth and stationary phase. Experientia 31:177-180 (1975). Press, G.

D. and Pitha, J.: Aging changes in uptake of polysaccharides by human diploid cells in culture. Mech. Age Dev. 3: 323-328 (1975).

Physiology, Cell Biology Bergman, B.; Sjöström, R., and Wing, K. R.: The variation with age of tissue zinc

Recent Articles in Ageing Research

247 
concentrations in albino rats determined by atomic absorption spectrophotometry. Acta physiol. scand. 92: 440-450 (1974).

David, J.; Cohet, Y., and Fouillet, P.: The variability between individuals as a measure of senescence: a study of the number of eggs laid and the percentage of hatched eggs in the case of Drosophila melanogaster. Expl Gerontol. 10: 17-26 (1975).

Maura, G. and Vaccari, A.: Relationships between age of submission to environmental stress and monoamine oxidase activity in rats. Experientia 31: 191-193 (1975).

Ooka, H.; Yamamoto, K.; Okuma, Y.; Suga, S., and Wakasugi, M.: The migratory activity of rat epidermal cells in vitro - age-related changes and the effect of serum. Expl Gerontol. 10: 79-84 (1975).

Rockstein, M. and Baker, G. T.: Effects of X-irradiation of pupae on aging of the thoracic flight muscle of the adult house fly, Musca domestica L. Mech. Age Dev. 3: 271-278 (1975).

Rosenthal, S. M. and LaJohn, L. A.: Effect of age on transvascular fluid movement. Am. J. Physiol. 228: 134-140 (1975).

Snook, J. T.: Effect of age and longterm diet on exocrine pancreas of the rat. Am. J. Physiol. 228: 262-268 (1975).

Stuchlíková, E.; Juricovâ-Horaková, M., and Deyl, Z.: New aspects of the dietary effect of life prolongation in rodents. What is the role of obesity in aging? Expl Gerontol. 10: 141-144 (1975). Young, V. R.; Steffee, W. P.; Pencharz, P. B.; Winterer, J. C, and Scrimshaw, N. S.: Total human body protein synthesis in relation to protein requirements at various ages. Nature, Lond. 253: 192-193 (1975).

Immunology

Brennan, P. C. and Jaroslaw, B. N.: Age-associated decline in theta-antigen on spleen thymusderived lymphocytes of B6CF1 mice. Cell Immunol. 15: 57-68 (1975).

Foad, B.S.I.; Khullar, S.; Freimer, E. H.; Kirsner, A. B., and Sheon, R. P.: Cell-mediated immunity in systemic lupus erythematosus: alterations with advancing age. J. Lab. clin. Med. 85: 132-139 (1975).

Gerbase-DeLima, M.; Meredith, P., and Walford, R. L.: Age-related changes, including synergy and suppression, in the mixed lymphocyte reaction in long-lived mice. Fed. Proc. 34: 159-161 (1975).

Makinodan, T. and Adler, W. H.: Effects of aging on the differentiation and proliferation potentials of cells of the immune system. Fed. Proc. 34: 153-158 (1975).

Miller, R. G. and Phillips, R. A.: Development of B lymphocytes. Fed. Proc. 34: 145-150 (1975). Mosier, D. E. and Cohen, P. L.: Ontogeny of mouse T lymphocyte function. Fed. Proc. 34: 137140 (1975).

Siskind, G. W. and Goidl, E. A.: Ontogeny of B lymphocyte function with respect to the heterogeneity of antibody affinity. Fed. Proc. 34: 151-152 (1975).

Weissman, I. L.; Small, M.; Fathman, C. G., and Herzenberg, L. A.: Differentiation of thymus cells. Fed. Proc. 34: 141-144 (1975).

Histology, Cytology and Comparative Anatomy Spoerri, P. E.; Glees, P., and El-Ghazzawi, E.: Accumulation of lipofuscin in the

248

Recent Articles in Ageing Research

myocardium of senile guinea pigs: dissolution and removal of lipofuscin following dimethylaminoethyl p-chlorophenoxyacetate administration. Mech. Age Dev. 3: 
311-321 (1975). Tauchi, H.; Sato, T., and Kobayashi, H.: Effect of age on ultrastructural changes of

cortisone treated mouse hepatic cells. Mech. Age Dev. 3: 279-290 (1975). Tonna, E. A.:

Accumulation of lipofuscin (age pigment) in aging skeletal connective

tissues as revealed by electron microscopy. J. Geront. 30: 3-8 (1975). Yeager, V. L.;

Chiemchanya, S., and Chaiseri, P.: Changes in size of lacunae during the

life of osteocytes in osteons of compact bone. J. Geront. 30: 9-14 (1975).

Pharmacology Rosner, L.: Safety of administration of procaine hydrochloride-hematoporphyrin

(KH3) to beagle dogs. J. Geront. 30: 41-46 (1975).

Longevity, Populations and Genetics

Forbes, W. F.: The effect of prednisolone phosphate on the life-span of DBA/2J mice. Expl

Gerontol. 10: 27-30 (1975).

Hieb, W. F. and Rothstein, M.: Aging in the free-living nematode Turbatrix aceti. Techniques for synchronization and aging of large-scale axenic cultures. Expl Gerontol. 10: 145-154 (1975).

Warren, S.; Chute, R. N., and Porter, M. W.: The effect of parabiosis on lifespan of rats stressed by radiation. J. Geront. 30: 15-21 (1975).

Psychology and Behaviour Müller, H. F.; Grad, B., and Engelsmann, F.: Biological and psychological predictors

of survival in a psychogeriatric population. J. Geront. 30: 47-52 (1975). Schonfield, D. and

Wenger, L.: Age limitation of perceptual span. Nature, Lond. 253:

377-378 (1975). Taub, H.: Mode of presentation, age, and short-term memory. J. Geront. 30: 5659

(1975). Wax, T. M.: The runwheel activity patterns of mature-young and senescent mice: the effect of constant lighting conditions. J. Geront. 30: 22-27 (1975). 